\title{
TŁUMACZE KONFERENCYJNI W PARLAMENCIE EUROPEJSKIM
}

DOI: http://dx.doi.org/10.12775/RP.2020.001

Zarys treści: Artykuł przedstawia środowisko pracy unijnych tłumaczy konferencyjnych w Parlamencie Europejskim ze szczególnym uwzględnieniem specyfiki sesji plenarnych. Duże wyzwanie stanowią teksty źródłowe, zwykle bardzo krótkie, szybkie, następujące bezpośrednio po sobie. Często zgłaszanym przez tłumaczy problemem jest również słaba angielszczyzna mówców używana zamiast języka ojczystego. Sporo uwagi poświęca się wieloetapowemu procesowi rekrutacji nowych tłumaczy. Następnie opisywane są badania etnograficzne nad tą grupą zawodową, wykorzystujące metody takie jak wywiady, kwestionariusze, obserwacja uczestnicząca.

Słowa kluczowe: tłumaczenie symultaniczne, tłumacz ustny, Parlament Europejski, badania etnograficzne

\section{Unia Europejska jako instytucja wielojęzyczna}

N ie ma obecnie instytucji międzynarodowej, która dorównywałaby Unii Europejskiej pod względem wielojęzyczności. Chociaż podczas rozrastania się UE były brane pod uwagę również inne opcje (przede wszystkim podczas przygotowań do bezprecedensowego rozszerzenia w 2004 r.), ostatecznie nie zdecydowano się ograniczyć liczby języków urzędowych. Co do zasady każde państwo członkowskie może zgłosić jeden taki język i obecnie jest ich 24, co daje aż 552 kierunki tłumaczenia (każdy z języków może być zarówno źródłowym, jak i docelowym dla pozostałych 23). W 2004 r. przybyło 9 nowych języków (czeski, estoński, litewski, łotewski, maltański, polski, słowacki, słoweński i węgierski), które dołączyły do 11 dotychczasowych. Dla służb tłu- 
maczeniowych oznaczało to ogromne wyzwania, włącznie z koniecznością umieszczenia w salach obrad dodatkowych kabin. Najnowszy język urzędowy (chorwacki) pojawił się w roku 2013. Chociaż rozważano możliwość wycofania angielskiego po brexicie, obecnie nie wydaje się to realne, mimo że nie będzie on formalnie językiem żadnego państwa członkowskiego. Irlandia w 2007 r. zastąpiła co prawda dotychczas deklarowany jako swój angielski gaelickim, ale zapowiada, że będzie w Radzie UE blokować odebranie angielskiemu statusu języka urzędowego (Buchowska 2017: 70).

Całkowity koszt wielojęzyczności prawdopodobnie przekracza obecnie miliard euro rocznie, $\mathrm{z}$ czego około $1 /{ }_{5}$ przypada na tłumaczenie ustne. Jest to bajońska kwota, jednak zwolennicy wielojęzyczności podkreślają, że stanowi to mniej niż 1\% unijnego budżetu (de Vincente 2011) i kosztuje unijnego obywatela około 2,30 euro rocznie - słowami Olgi Cosmidou, byłej szefowej Dyrekcji Generalnej zapewniającej tłumaczenia ustne w Parlamencie Europejskim, można powiedzieć, że "cena filiżanki kawy to cena za demokrację"1 (Cosmidou 2013: 130). Średni koszt jednej przetłumaczonej strony wynosi jednak około 150-180 euro (Phillipson 2003, Pym 2008), co jest nieporównywalne z cenami tłumaczeń pisemnych na wolnym rynku. $Z$ danych Komisji Europejskiej (b.d.) wynika zaś, że jeden dzień pracy tłumacza ustnego kosztuje europejskich podatników ponad 1200 euro.

Spośród unijnych instytucji Parlament Europejski (PE) najbardziej konsekwentnie stosuje się do zasady wielojęzyczności. Nie oznacza to, że wszystkie spotkania w PE (takie jak grupy robocze czy spotkania poszczególnych frakcji politycznych) odbywają się w 24 językach, jednak uczestnicy każdego spotkania mają możliwość poprosić odpowiednio wcześniej o uwzględnienie ich języka. Pełna wielojęzyczność obowiązuje natomiast podczas sesji plenarnych PE, które odbywają się najczęściej dwa razy w miesiącu w Strasbourgu i w sumie zajmują około 430 godzin rocznie (Parlament Europejski 2013). Sesje plenarne są transmitowane na żywo na stronie internetowej PE, dowolną sesję czy pojedyncze przemówienie z bieżącej jak również poprzedniej kadencji można też zawsze bezpłatnie ściągnąć ze strony w formie pliku audio lub wideo $\mathrm{w}$ oryginale lub w wybranym języku urzędowym (https://multimedia.europarl.europa.eu/pl/webstreaming?lv=PLENARY $)^{2}$. Ma to na celu umożliwienie wyborcom sprawowania demokratycznej kontroli nad swoimi przedstawicielami, ale niezamierzenie stworzono również nieocenione źró-

${ }^{1}$ Oryg.: „The price of a cup of coffee is the price of democracy”. Wszystkie thumaczenia cytatów z języka angielskiego w tym artykule wykonała jego autorka - M. B.

${ }^{2}$ Przeprowadzona wiosną 2020 r. przebudowa strony PE niestety znacznie utrudniła poszukiwania, a niektóre materiały są obecnie dostępne tylko w kilku językach. 
dło łatwo dostępnego i niezwykle bogatego materiału dla badaczy tłumaczenia ustnego, z którego skwapliwie korzystają do prowadzenia badań korpusowych (zob. m.in. Beaton-Thome 2013, Kajzer-Wietrzny 2013, Bartłomiejczyk 2016, Magnifico, Defrancq 2017, Defrancq, Plevoets 2018, Kučiš, Majhenič 2018). Brak konieczności wcześniejszego uprzedzania tłumaczy o zamiarze nagrywania ich tłumaczeń na potrzeby analizy stanowi dodatkowy atut, gdyż zapobiega wywieraniu wpływu na ich zachowanie przez nieobecnego na co dzień obserwatora z zewnątrz.

Należy wspomnieć, że wszystkie przemówienia plenarne są spisywane i baza stenogramów posiedzeń jest również ogólnodostępna (https://www. europarl.europa.eu/plenary/pl/debates-video.html). Do czerwca 2011 r. przemówienia były tłumaczone pisemnie na wszystkie języki, jednak był to proces dość długotrwały (od wygłoszenia danej mowy do jej udostępnienia we wszystkich wersjach językowych mijały nawet cztery miesiące). Nawiasem mówiąc, również te tłumaczenia bywały przedmiotem badań przekładoznawczych (np. Calzada Pérez 2001, Loupaki 2008). W 2011 r. Biuro PE zdecydowało w celu redukcji kosztów o ograniczeniu tłumaczenia pisemnego do angielskiego jako jedynego języka docelowego. Wywołało to protesty jako niezgodne z zasadami wielojęzyczności (faworyzowanie jednego języka). Ostatecznie 20 listopada 2012 r. przegłosowano zmianę w Regulaminie PE, na mocy której obecnie wszystkie stenogramy publikowane są jako dokumenty wielojęzyczne zawierające każde przemówienie $\mathrm{w}$ oryginale. $\mathrm{W}$ rezultacie tłumaczenia symultaniczne stały się jedynym dostępnym dla ogółu źródłem informacji o treści wypowiedzi w nieznanych słuchaczowi językach obcych. Brak tłumaczeń pisemnych może wywierać dodatkową presję na tłumaczy ustnych, mimo że ich tłumaczenia udostępniane są z następującą klauzulą:

Tłumaczenie ustne nie stanowi dokładnego zapisu obrad.

Parlament Europejski zapewnia tłumaczenie ustne debat wyłącznie w celu ułatwienia komunikacji między uczestnikami posiedzenia. Tłumaczenie ustne w żadnym wypadku nie stanowi wiarygodnego zapisu posiedzenia.

Wiarygodnym źródłem jest wyłącznie oryginalne przemówienie lub jego tłumaczenie pisemne po korekcie.

W razie rozbieżności między tłumaczeniem ustnym a oryginalnym przemówieniem (lub jego tłumaczeniem pisemnym po korekcie) decyduje oryginalne przemówienie (lub jego tłumaczenie pisemne po korekcie). [...] fragmentów.

${ }^{3}$ Europarlamentarzyści zawsze mogą poprosić o tłumaczenie pisemne interesujących ich 
Wykorzystanie nagrania tłumaczenia ustnego do celów innych niż określony powyżej bez wyraźnego zezwolenia Parlamentu Europejskiego jest ściśle wzbronione. (nota, https://multimedia.europarl.europa.eu/pl/plenary_20200723-0900-PLENARY_vd, dostęp: 23.08.2020)

Powyższa klauzula jest właściwie myląca, ponieważ sugeruje odbiorcy dostępność tłumaczeń pisemnych. Poza tym stoi w pewnej sprzeczności z oficjalnym dyskursem unijnych służb odpowiedzialnych za tłumaczenie ustne prezentowanym w innych miejscach (np. na profilu facebookowym czy własnej stronie internetowej), gdzie twierdzi się, że tłumacze „przekazują tę samą informację dokładnie i prawie natychmiast w innym języku”, "naturalnie, płynnie, przejmując sposób prezentacji, ton i przekonania mówcy"5 (zob. Bartłomiejczyk 2016: 252, 254).

Potencjalna wartość tłumaczeń symultanicznych z PE jako materiału badawczego została zauważona przez Carlo Marzocchiego (1998). Obecna dostępność nagrań w internecie sprawia, że pojedyncze mowy czy też niewielkie korpusy mogą być analizowane nawet przez studentów w ramach pracy magisterskiej lub licencjackiej. Mariachiara Russo (2010) opisuje kilka prac dyplomowych w języku włoskim z Uniwersytetu Bolońskiego, w Polsce powstawały takowe m.in. na Uniwersytecie Śląskim (np. Lejkowska-Abdelhazer 2018) czy Uniwersytecie Gdańskim (np. Koturbasz 2012).

Obfitość i różnorodność badań korpusowych na materiale z PE jest obecnie tak wielka, że ich opis wykracza daleko poza limity objętościowe tego artykułu. Pokrótce można zauważyć, że większość badaczy analizuje samodzielnie skompilowane pod kątem konkretnego pytania badawczego korpusy, których rozmiar ogranicza przede wszystkim pracochłonność transkrypcji tłumaczeń (jako teksty źródłowe można wykorzystać dostępne stenogramy, po niewielkiej korekcie). Korpusy takie nie są udostępniane, można się zapoznać co najwyżej z ich fragmentami (np. książka Bartłomiejczyk 2016 w załączniku zawiera 10 przemówień wraz z tłumaczeniami, podczas gdy cały korpus obejmuje ich 218).

Korpusy przeznaczone do szerszego wykorzystania zostały stworzone przez zespoły badawcze na Uniwersytecie Bolońskim (European Parliament Interpretation Corpus (EPIC)) i Uniwersytecie Gandawskim (European Parliament interpreting corpus Ghent (EPICG)). EPIC zawiera oryginały i tłu-

${ }^{4}$ Oryg.: „render that same message accurately and almost instantly in another [language]”.

5 Oryg.: ",naturally and fluently, adopting the delivery, tone and convictions of the speaker". 
maczenia w językach angielskim, włoskim i hiszpańskim, w sumie prawie 8 godzin tekstów źródłowych z 2004 r. (zob. Spinolo, Garwood 2010). Dostęp jest płatny, kosztuje 750 euro. EPICG zawiera teksty źródłowe z 2006 i 2008 r. w językach francuskim i hiszpańskim oraz tłumaczenia na angielski i flamandzki, jest to projekt stosunkowo nowy i wciąż kontynuowany, dlatego trudno podać informacje na temat jego aktualnego rozmiaru (zob. Magnifico, Defrancq 2017, Defrancq, Plevoets 2018). Nie ma do niego dostępu on-line dla naukowców spoza Uniwersytetu Gandawskiego. Nie posiadam informacji o jakimkolwiek gotowym do wykorzystania $\mathrm{w}$ badaniach korpusie tego typu $\mathrm{z}$ materiałem w języku polskim, jednak co najmniej dwa takie projekty mają zostać sfinalizowane w roku 2021.

\section{Zasady zatrudniania tłumaczy konferencyjnych przez instytucje unijne}

Rekrutacją tłumaczy konferencyjnych oraz koordynacją ich pracy zajmują się trzy jednostki: największa Dyrekcja Generalna ds. Tłumaczeń Ustnych (Interpretation, DG SCIC), obsługująca Komisję Europejską oraz większość unijnych instytucji nieposiadających własnych służb tłumaczeniowych, Dyrekcja Generalna ds. Logistyki i Tłumaczenia Konferencyjnego (DG LINC), obsługująca Parlament Europejski, oraz Dyrekcja Tłumaczeń Konferencyjnych, obsługująca Trybunał Sprawiedliwości UE. Wyżej wymienione dyrekcje zatrudniają odpowiednio ok. 600, 430 i 70 etatowych tłumaczy ustnych, a ponadto w razie potrzeby mogą się zwrócić do ponad 3000 akredytowanych tłumaczy pomocniczych, z którymi zawierane są krótkoterminowe umowy. Parlament korzysta na bardzo dużą skalę z usług tych drugich: już w $2011 \mathrm{r}$. blisko połowa tłumaczeń ustnych $(47,74 \%)$ była wykonywana przez wolnych strzelców (Parlament Europejski 2013).

Drogą do zatrudnienia na etacie jest wygranie otwartego konkursu, obecnie jednak są one ogłaszane bardzo rzadko (większość polskich etatowych tłumaczy została zatrudniona krótko przed przystąpieniem Polski do UE lub krótko po nim). Poza tym konkursy najczęściej wygrywane są przez kandydatów posiadających wcześniejsze doświadczenie jako tłumacze pomocniczy (Duflou 2016: 131). Testy akredytacyjne dla kandydatów na tłumaczy pomocniczych są organizowane dosyć regularnie. Podanie składa się on-line. Instytucje unijne ogłaszają swoje aktualne zapotrzebowanie na tłumaczy w danych kombinacjach językowych. Obecnie (lata 2018-2020) kandydat na tłumacza z językiem polskim jako ojczystym powinien opanować co najmniej jeden aktywny i jeden pasywny język obcy (ABC, wedle termino- 
logii stowarzyszenia AIIC) lub trzy pasywne języki obce (ACCC), przy czym w każdym przypadku angielski jest obowiązkowy, a w kombinacji musi się znaleźć dodatkowo niemiecki, francuski, włoski lub hiszpański. Dla wielu rzadszych języków ojczystych wystarczy jeden aktywny język obcy. Kandydat musi posiadać wykształcenie wyższe (licencjackie lub magisterskie) w dziedzinie tłumaczenia konferencyjnego lub jakiekolwiek inne wykształcenie wyższe plus roczny kurs podyplomowy tłumaczenia konferencyjnego albo udokumentowany rok pracy w charakterze tłumacza konferencyjnego.

Od 2016 r. kandydaci wybrani na podstawie przesłanych dokumentów są poddawani wstępnemu testowi on-line, który polega na tłumaczeniu symultanicznym na swój język ojczysty tekstu długości 10-12 minut. Po pomyślnym przejściu tego testu kandydat może być zaproszony na testy akredytacyjne do Brukseli, gdzie będzie musiał znów wykazać się umiejętnością tłumaczenia symultanicznego tekstu o podobnej długości oraz tłumaczenia konsekutywnego tekstu o długości ok. 6 minut dla każdej zgłoszonej kombinacji językowej, na którą istnieje zapotrzebowanie. Znajomość terminologii i problematyki unijnej nie jest sprawdzana osobno, przynajmniej jeden $\mathrm{z}$ tekstów źródłowych zawiera tego rodzaju elementy. Testy akredytacyjne zdaje około 30\% kandydatów (Duflou 2016: 130), w razie niepowodzenia obiecujący kandydaci mogą zostać jeszcze dwukrotnie zaproszeni do ich powtórzenia.

Należy mieć świadomość, że wpisanie na listę akredytowanych tłumaczy nie oznacza, że instytucje unijne zobowiązują się do zapewnienia danej osobie jakichkolwiek zleceń. W praktyce decydujące znaczenie ma najczęściej zadeklarowane miejsce zamieszkania tłumacza i jedynie tłumacze mieszkający w Brukseli i w okolicach mogą liczyć na regularną współpracę. Dzieje się tak dlatego, że zatrudnienie tłumacza spoza Brukseli kosztuje UE około trzy razy więcej (konieczność pokrycia kosztów zakwaterowania, wypłaty ryczałtu za dojazd, diet itp.). Aby zachęcić tłumaczy świeżo po testach do przeniesienia się do Brukseli, wybranym oferuje się uczestnictwo w programie „Newcomers' scheme”, który polega na zagwarantowaniu co najmniej 100 dni pracy w ciągu pierwszych 18 miesięcy. Warunkiem jest miejsce zamieszkania w Brukseli. Oczywiście oprócz pracy dla instytucji unijnych tłumacz może również wykonywać zlecenia na wolnym rynku. Program ten wydaje się atrakcyjny, jeżeli weźmiemy pod uwagę stawki dzienne netto 330 euro dla początkujących tłumaczy, przy czym dla doświadczonych (powyżej $250 \mathrm{dni}$ pracy dla instytucji unijnych) stawka wzrasta do 420 euro. Dodatkowo tłumaczom opłacane jest ubezpieczenie zdrowotne, a na ich prywatne konto emerytalne wpływa za każdy dzień 104 lub 144 euro (odpowiednio dla początkujących i doświadczonych). 


\section{Sesje plenarne ze szczególnym uwzględnieniem charakterystyki tekstów źródłowych}

Podczas każdej sesji plenarnej w Strasbourgu pracuje około tysiąc tłumaczy konferencyjnych, zarówno etatowych, jak i wolnych strzelców. Ze względu na wysoki stopień trudności oraz udostępnianie tłumaczeń szerokiej publiczności do obsługi tych sesji wyznaczani są z zasady tłumacze posiadający już kilkuletnie doświadczenie w tłumaczeniu mniej eksponowanych spotkań i których kompetencji przełożeni są pewni (Duflou 2016: 146).

Tłumacze pracują $\mathrm{w}$ przeszklonych kabinach usytuowanych w półokręgu u góry w sali plenarnej, widzą zatem mówcę (również zbliżenie na monitorze) i publiczność oraz są do pewnego stopnia dla nich widoczni. Kabiny są ponumerowane i przyporządkowane poszczególnym językom urzędowym. W każdej kabinie pracuje zazwyczaj trzech tłumaczy, których zadaniem jest tłumaczenie na swój język docelowy wszystkich wypowiedzi w innych językach. To oznacza, że (przynajmniej potencjalnie) zapewniają oni tłumaczenia z 23 języków. Jak można się domyślić, nie jest realne, aby trzyosobowy zespół w sumie znał wszystkie te języki - każdy tłumacz musiałby wtedy władać 7-8 językami obcymi i poza tym nie mogłyby się one pokrywać. Jeżeli zatem na sali używany jest język, którego żaden $\mathrm{z}$ trzech tłumaczy nie ma w swoim repertuarze, stosowane jest tłumaczenie relay, tzn. za pośrednictwem innego języka zwanego pivot (najczęściej angielskiego, niemieckiego lub francuskiego). Takie dwuetapowe tłumaczenie oczywiście pociąga za sobą większe opóźnienie w przekazie informacji i większe ryzyko błędów czy opuszczeń, a rola tłumacza produkującego tekst źródłowy dla swoich kolegów staje się szczególnie odpowiedzialna i stresująca (zob. Čeňková 2015).

Ogólnie przyjęta w PE zasada mówi, że powinno się tłumaczyć z języków obcych na swój język ojczysty. Konsekwentne jej stosowanie stało się jednak nierealne już w 1995 r. wraz z wprowadzeniem języka fińskiego. Zatrudnienie odpowiedniej liczby tłumaczy władających tym językiem jako obcym okazało się niemożliwe i podobnie wygląda sytuacja $\mathrm{z}$ wieloma młodszymi językami urzędowymi, między innymi polskim, węgierskim czy rumuńskim. W rezultacie tłumacze władający tymi bardziej „egzotycznymi” językami jako ojczystymi są często proszeni o tłumaczenie z nich na język obcy (tzw. tłumaczenie retour), przede wszystkim angielski, również w celu zapewnienia zrozumiałego tekstu źródłowego dla większości kabin, które będą w takiej sytuacji wykonywać tłumaczenie relay.

Mówcy mają możliwość wypowiadać się w swoim języku ojczystym, ale nie zawsze $\mathrm{z}$ niej korzystają. Wielu $\mathrm{z}$ nich posługuje się angielskim jako 
językiem obcym, którym nie wszyscy mówią płynnie. Ten stan rzeczy odzwierciedla wysoki udział tekstów w języku angielskim - 29,1\%, podczas gdy najliczniej reprezentowany język ojczysty, czyli niemiecki, osiąga 13,6\% (Parlament Europejski 2013). Tematyka jest bardzo szeroka, jako że obejmuje wszelkie obszary będące przedmiotem regulacji prawnych na szczeblu unijnym. Przemówienia mają zatem często bardzo specjalistyczny charakter, chociaż zdarzają się też dużo bardziej ogólne mowy okolicznościowe (np. z okazji ważnych rocznic lub wręczania Nagrody Sacharowa). W odróżnieniu od typowej konferencji przemówienia poszczególnych europosłów są zazwyczaj bardzo krótkie i większość z nich mieści się w przedziale 1-5 minut - wynika to $\mathrm{z}$ bardzo surowych zasad przydziału czasu przedstawicielom poszczególnych frakcji. Niewielkie przekroczenia przyznanego czasu są nagminne i zazwyczaj tolerowane przez przewodniczącego, o ile mówca nie odbiega zbytnio od tematu. Jedyne osoby, którym pozwala się na znacznie dłuższe wypowiedzi (nawet kilkunastominutowe), to przedstawiciele Komisji Europejskiej lub Rady Europejskiej, a czasem również specjalni goście (np. głowy państw spoza UE).

Jak twierdzi Marzocchi (1998: 70), przemówienia plenarne są „absurdalnie krótkie", w wyniku czego mówcy usiłujący zmieścić w nich jak najwięcej treści narzucają czasem tak szybkie tempo wypowiedzi, że zmuszają tłumaczy do poddania się i wyłączenia mikrofonu. Cristina Monti i in. (2005) szacują średnie tempo na około 150 słów na minutę. Wedle ich klasyfikacji wypowiedzi w PE do 130 słów na minutę są uznawane za wolne, w przedziale 131-160 - za średnie, a powyżej 160 - za szybkie. Optymalne tempo do tłumaczenia symultanicznego, jak sprawdzono eksperymentalnie, to 95-120 słów na minutę (Pöchhacker 2004: 129-130). Zdecydowana większość przemówień w PE charakteryzuje się zatem zbyt szybkim tempem mówienia, aby można je uznać za komfortowe dla tłumacza. Często są one również odczytywane bez wcześniejszego udostępnienia tekstu tłumaczom.

Chociaż przemówienia plenarne teoretycznie są głosami w debacie na konkretny temat, wiele $\mathrm{z}$ nich robi wrażenie tekstów skierowanych nie tyle do europarlamentarzystów i innych osób zgromadzonych w sali, a raczej do wyborców w kraju (zob. Loupaki 2008: 106, Kent 2009: 57). Takie nastawienie nadawcy odbija się bardzo negatywnie na jakości tekstu źródłowego postrzeganej z perspektywy tłumacza: mówcy po prostu nie zależy na komunikacji z obcojęzycznymi słuchaczami. Chociaż służby tłumaczeniowe starają się w miarę możliwości edukować mówców na temat właściwej współpracy z tłumaczami symultanicznymi (na przykład przez zapraszanie ich na spotkania czy publikację materiałów informacyjnych), część z nich całkowicie ignoruje 
wszelkie prośby i napomnienia. Dobrym przykładem tego problemu jest wystąpienie wiceprzewodniczącego Miguela Angela Martíneza z 25 marca 2009 r. (zob. Bartłomiejczyk 2017: 171), w którym cytuje on ulotkę przeznaczoną dla nowych europosłów. Rady tam zawarte to m.in.: utrzymywanie stałego i niezbyt szybkiego tempa, używanie języka ojczystego, mówienie zamiast czytania, w razie czytania udostępnienie tekstu tłumaczom, wyraźne wypowiadanie liczb, wyjaśnianie skrótowców, wcześniejsze komunikowanie się z tłumaczami co do zaplanowanych żartów. Wiceprzewodniczący apeluje do widowni o lepszą współpracę z tłumaczami, jednak pełna ironia tej sytuacji dociera do nas dopiero, gdy zdamy sobie sprawę, że mówi to wszystko dwa miesiące przed zakończeniem kadencji PE. Do tego czasu wszyscy powinni byli już dawno przyswoić sobie wymieniane przez niego zasady.

Rolą prowadzącego obrady jest zwracanie uwagi mówcom, a tłumacze mają możliwość zgłoszenia mu problemów z nadążaniem przez włączenie czerwonego światełka na jego pulpicie. Niekiedy jednak europosłowie calkowicie otwarcie odmawiają współpracy, na przykład napomniany Charles Tannock deklaruje: „[...] wszyscy rozumieją angielski. [...] Będę mówił tak szybko, jak mi się podoba"' (Bartłomiejczyk 2017: 171). Sam (wice)przewodniczący nie zawsze pamięta o ograniczeniach narzucanych przez tłumaczenie i zdarza się, że głosowania przeprowadzane są o wiele za szybko. W rezultacie kiedy europosłowie słuchający oryginału reagują na pytanie „Kto jest przeciw?” lub „Kto się wstrzymał?”, ci korzystający z tłumaczeń (w szczególności w systemie relay) mogą w słuchawkach słyszeć dopiero pytanie „Kto jest za?”. Ten zasadniczy problem zgłaszali m.in. europosłowie Giles Chichester i Dobromir Sośnierz.

Najnowszym wyzwaniem powstałym w 2020 r. w związku z pandemią koronawirusa jest zdalny udział europosłów w obradach. Słaba jakość połączenia, a szczególnie dźwięku, może się w sposób oczywisty przekładać na problemy z tłumaczeniem. Znalazło to odzwierciedlenie we fragmencie dodanym do wspomnianej wcześniej klauzuli towarzyszącej tłumaczeniom udostępnianym na stronie PE: „W przypadku posiedzeń z udziałem osób łączących się na odległość jakość połączenia zdalnego może wpływać na jakość dźwięku i obrazu, a w konsekwencji również na jakość tłumaczenia" (nota, https://multimedia.europarl.europa.eu/pl/plenary_20200723-0900-PLENARY_vd, dostęp: 23.08.2020). Jest to kwestia całkiem nowa i dotychczas nie podejmowana przez badaczy, zatem ograniczę się jedynie do wzmianki.

${ }^{6}$ Oryg.: „[...] everybody understands English. [...] I will speak at the speed I wish to”. 
Na korzyść tłumaczy działa natomiast stosunkowo duża przewidywalność tekstów źródłowych, co stwarza wysoki potencjał do antycypowania treści bądź też, w razie problemów, do odtwarzania jej na podstawie kontekstu. Powtarzalność głoszonych przez mówców poglądów wynika zarówno z tego, że podczas jednej kadencji PE wielokrotnie zabierają głos te same osoby, jak i z przynależności mówców do kilku frakcji o pewnym stopniu ideologicznej spójności. Powtarzają się również bardzo często liczne słowa kluczowe oraz kolokacje, jak np. rzeczownik solidarity w kombinacji z przymiotnikami takimi jak European i multinational (Beaton 2007: 111-112). Dzięki temu doświadczeni tłumacze mogą sobie stworzyć mentalną bazę gotowych rozwiązań tłumaczeniowych na takie powtarzalne elementy, a rozwiązania te często są przejmowane od kolegów z tej samej kabiny. Line Henriksen (2007) pokazuje $\mathrm{w}$ swoim badaniu paraeksperymentalnym, że duńscy tłumacze unijni posiadają wspólny repertuar „formuł”, chociaż część z nich skłania się do uciekania od nich na rzecz rozwiązań bardziej idiosynkratycznych. Kolejnym źródłem przewidywalności jest intertekstualność przemówień, które często odnoszą się do projektów legislacyjnych udostępnianych również tłumaczom, którzy tym samym mają możliwość odpowiedniego przygotowania się do tłumaczenia debaty. Jak zauważa Anna-Riitta Vuorikoski (2004: 80), w szczególnie korzystnej sytuacji są ci tłumacze, którzy już wcześniej tłumaczyli spotkania komisji przygotowującej dany dokument.

Podsumowując, dyskurs plenarny w PE posiada wiele cech, które mają bardzo istotny (negatywny lub pozytywny) wpływ na tłumaczenie symultaniczne. Niektóre z nich są unikalne dla tego konkretnego środowiska pracy.

\section{Badania etnograficzne}

Oprócz licznych badań korpusowych istnieje kilka ciekawych prac o charakterze etnograficznym skupiających się na samych tłumaczach. Szczególnie obszerne są doktoraty dwóch badaczek napisane z całkowicie odmiennych perspektyw. Stephanie Jo Kent (2014) obserwuje funkcjonowanie PE jako tłumaczka języka migowego i stypendystka Fulbrighta ze Stanów Zjednoczonych, a Veerle Duflou (2016) - jako doświadczona tłumaczka unijna pracująca jako wolny strzelec w kabinie flamandzkiej.

Chociaż próby opisu realiów pracy w PE zostały podjęte już wcześniej (Marzocchi 1998, Vuorikoski 2004), pierwszą wedle mojej wiedzy pracą na ten temat wykorzystującą metodologię typowo etnograficzną jest artykuł Kent (2009). W 2005 r. badaczka przeprowadziła wywiady z 65 tłumaczami 
pracującymi dla PE i reprezentującymi wszystkie języki urzędowe. Zapytała ich o spostrzeżenia dotyczące komunikacji w PE oraz o wyzwania i problemy, $\mathrm{z}$ jakimi spotykają się w codziennej pracy. Uzyskany materiał jest poddawany krytycznej analizie dyskursu, co do obiektywizmu tej analizy można mieć jednak pewne wątpliwości. Autorka maluje ponury obraz pracy w PE, o czym świadczy dobitnie już sam tytuł artykułu: Dyskurs niebezpieczeństwa i straty (A discourse of danger and loss). Wszelkie pozytywne impresje respondentów są traktowane jako „retoryka promocyjna” i krótko podsumowywane: „Znaczna część dyskursu tłumaczy w PE odzwierciedla publiczną retorykę Unii Europejskiej o demokracji i równości”7 (Kent 2009: 62). Badaczka najwyraźniej uważa również, że „jedynie symboliczna” (tamże) wartość tłumaczeń symultanicznych nie usprawiedliwia ponoszonych na nie wydatków. Główny problem wymieniany przez respondentów to fakt, że mówcy często decydują się używać (słabo opanowanego) języka angielskiego jako lingua franca zamiast swojego języka ojczystego. Istnieje wówczas niebezpieczeństwo, że ich prawdziwe intencje mogą nie być jasne dla tłumacza, co skutkuje stratą informacji. Innym, nieco mniej palącym, problemem jest szybkie odczytywanie wcześniej przygotowanych tekstów.

W swojej późniejszej pracy doktorskiej Kent (2014) prezentuje znacznie bardziej wyważoną analizę tych samych wywiadów, interpretując frustrację i liczne problemy jako przejściowy skutek ogromnych zmian organizacyjnych, które dotknęly tłumaczy w 2004 r. Nowe dane poddawane tutaj dodatkowo analizie jakościowej to wywiady z 55 europosłami oraz pracownikami EP i obserwacje terenowe wykonane przede wszystkim poza sesjami plenarnymi. W tych wywiadach również pojawiają się negatywne akcenty, jako że mówcy komunikujący się w języku angielskim jako obcym podają najczęściej jako powód brak zaufania do tłumaczenia symultanicznego i lęk o utratę kontroli nad treścią swoich wypowiedzi. Jednocześnie zdają sobie oni sprawę z własnych ograniczeń związanych z przemawianiem w języku innym niż ojczysty. Użytkownicy narzekają również na nieuniknione podczas tłumaczenia opóźnienie czasowe, które może prowadzić do zamieszania (szczególnie podczas głosowań). Bardzo ciekawe spostrzeżenia wynikają z obserwacji spotkań grup roboczych i frakcji. Autorka zauważa między innymi tendencję do przechodzenia na język ojczysty w momencie, gdy dyskusja staje się szczególnie ożywiona, a temat jest kontrowersyjny. Ponadto twierdzi, że istnieje presja społeczna na radzenie sobie bez pośrednictwa tłumaczy, która

\footnotetext{
7 Oryg.: „Much of the EP interpreters' discourse mirrors the European Union's public rhetoric about democracy and equality".
} 
jest na tyle silna, że uczestnicy spotkań unikają zakładania słuchawek nawet w sytuacjach, gdy oczywista jest ich nieznajomość języka źródłowego. Takie przypadki mogą również stanowić wytłumaczenie, dlaczego mówcy wolą nie przemawiać w swoich językach ojczystych, o ile nie są one szeroko rozpowszechnione.

Książka Duflou (2016) opiera się na materiale uzyskanym podczas wywiadów, a także prowadzonej systematycznie przez cztery lata obserwacji uczestniczącej. Kładzie ona nacisk na tłumaczenie jako pracę zespołową, a w szczególności na kompetencje i umiejętności, które tłumacze unijni muszą nabyć jako przystępujący do pracy nowicjusze już po zdaniu testów akredytacyjnych. Najbardziej szczegółowa część opracowania dotyczy podziału zadań tłumaczeniowych pomiędzy tłumaczy pracujących w tej samej kabinie. Jest to kwestia skomplikowana, jeśli weźmie się pod uwage liczbę używanych języków źródłowych oraz fakt, że ich znajomość w kabinie częściowo się pokrywa. Przydział tekstów poszczególnym tłumaczom jest umotywowany dążeniem do sprawiedliwego rozdzielenia zadań, ale również naczelną zasadą unikania tłumaczenia relay, o ile dany język źródłowy jest w repertuarze przynajmniej jednego ze współpracujących w kabinie tłumaczy. Funkcjonuje również wiele innych, drugorzędnych zasad: unikanie zmiany tłumacza $\mathrm{w}$ czasie trwania przemówienia, preferencja dla półgodzinnych okresów pracy kończących się o pełnych kwadransach (tzn. o pełnej godzinie, 15, 30 lub 45 minut po) czy też przydzielanie początkowej części sesji najbardziej doświadczonemu tłumaczowi. Negocjacje co do przydziału tekstów rzadko odbywają się przed rozpoczęciem sesji, zatem muszą opierać się przede wszystkim na komunikacji niewerbalnej. Pomimo tych trudności podczas większości analizowanych przez Duflou sesji tłumaczom udało się doprowadzić do w miarę równego podziału czasu pracy za mikrofonem.

Inne interesujące obserwacje badaczki obejmują między innymi ważną rolę „podsłuchiwania”. Często ignoruje się fakt, że tłumaczy słuchają nie tylko uczestnicy spotkania, ale również ich koledzy w danej kabinie, a nieraz nawet w innych kabinach. To na użytek swoich kolegów tłumacze stosują barwne idiomy i eleganckie wyrażenia, które niekoniecznie przyczyniają się do zrozumiałości tekstu docelowego. Wywiady pokazują również, że tłumacze często zapożyczają pewne rozwiązania (zarówno ekwiwalenty poszczególnych elementów w języku źródłowym, jak i strategie tłumaczeniowe mające zastosowanie do konkretnego typu problemów), szczególnie od bardziej doświadczonych współpracowników. Ma to niewątpliwie wpływ na kształtowanie się wspólnych norm, przynajmniej w ramach jednej kabiny. 
W porównaniu z opisanymi wyżej doktoratami artykuły Helle Van Dam i Karen Korning Zethsen (2013) oraz Madaleny Bartłomiejczyk (2017) są pracami o znacznie skromniejszym zakresie, opartymi na innych metodach badawczych. Van Dam i Zethsen analizują dane z kwestionariuszy wypełnionych on-line przez unijnych etatowych tłumaczy języka duńskiego - pisemnych i ustnych (odpowiednio 63 i 23 respondentów). Autorki badają postrzeganie przez tłumaczy ich statusu zawodowego, mierzonego za pomocą pięciu parametrów: wynagrodzenia, wiedzy, widoczności, wpływu oraz wartości dla społeczeństwa. Ankieta składa się przede wszystkim z pytań zamkniętych, polegających na wybieraniu odpowiedzi na pięciostopniowej skali. Co ciekawe, respondentów zapytano zarówno o ich subiektywne odczucia, jak i o to, jak ich zdaniem ich status zawodowy jest oceniany przez osoby z zewnątrz.

Biorąc pod uwagę stereotyp tłumaczenia konferencyjnego jako bardzo prestiżowego, dobrze płatnego i ekscytującego zajęcia, autorki założyły, że tłumacze ustni będą postrzegać siebie jako "gwiazdy profesji tłumaczeniowej" (Van Dam, Zethsen 2013: 229) i bardzo wysoko ocenią swój status zawodowy, odpowiadając na szereg pytań w skali od 1 (niski) do 5 (wysoki). Hipoteza ta raczej się nie potwierdziła, jako że średnia sumaryczna ocena wyniosła 3,39, czyli tylko trochę powyżej środka skali (3). Ta ocena była jednak znacznie wyższa niż w przypadku tłumaczy pisemnych: 2,56. Jedyny parametr, z którego zarówno tłumacze ustni, jak i pisemni byli wyraźnie zadowoleni, to wynagrodzenie, wynoszące miesięcznie od 9300 do 9900 euro. Tłumacze ustni nie uważali siebie za bardzo widocznych (3,00 w porównaniu z 2,70 dla tłumaczy pisemnych) ani szczególnie docenianych przez swoich klientów $(3,22 \mathrm{w}$ porównaniu z 3,02$)$. Wpływ wywierany przez ich pracę został oceniony jedynie na 1,96 (w porównaniu z 2,06 dla tłumaczy pisemnych). Mimo że zarówno tłumacze ustni, jak i pisemni, mieli poczucie wysokiej wartości swojej pracy (odpowiednio 3,70 i 3,94), w pytaniu otwartym na koniec ankiety jeden z tłumaczy zwrócił uwagę na drastyczny spadek tego poczucia w przypadku oczywistego braku zainteresowania ze strony słuchaczy. Podobna kwestia wypłynęła podczas rozmów autorek z tłumaczami: duńscy europosłowie posługują się najczęściej językiem angielskim i tłumacze czują się $\mathrm{w}$ rezultacie bezużyteczni.

Podobnie jak u Kent $(2009,2014)$ również wyniki Van Dam i Zethsen (2013) sugerują, że poziom satysfakcji unijnych tłumaczy ustnych z wykonywanej pracy nie jest tak wysoki, jak można by oczekiwać na podstawie ich imponującej płacy, przewidywalnych i stosunkowo komfortowych warunków pracy oraz prestiżu. Powodem takiego stanu rzeczy wydaje się być przede wszystkim negatywne bądź obojętne nastawienie klientów, z którymi tłuma- 
cze mają bezpośredni kontakt, czyli europosłów oraz urzędników unijnych. Kolejnym krokiem do zbadania tego nastawienia jest artykuł Bartłomiejczyk (2017), skupiający się na przejawach widoczności tłumaczy w dyskursie plenarnym.

Analizowany materiał obejmuje wszystkie przemówienia plenarne z okresu ośmiu lat (2005-2012) udostępnione na stronie internetowej EP $\mathrm{w}$ formie anglojęzycznych stenogramów. Jako że analiza manualna takiej ilości materiału nie byłaby możliwa, zastosowano metodę automatycznego wyszukiwania słów kluczowych, a mianowicie interpreter, interpretation, translator i translation, których kontekst był następnie analizowany w celu ustalenia, czy dany fragment odnosi się do tłumaczy ustnych w PE i ich pracy $\mathrm{w}$ trakcie danej sesji. Znaleziono 230 takich fragmentów o różnej długości. W porównaniu $\mathrm{z}$ liczbą dni, w których odbywały się w badanym okresie sesje plenarne (483), można wyciągnąć wniosek, że mówcy plenarni jako ogół odnoszą się w swoich wypowiedziach do tłumaczy mniej więcej co drugi dzień. Zidentyfikowane fragmenty poddano analizie tematycznej, która pozwoliła wyodrębnić kilka odrębnych kategorii.

W przeciwieństwie do oczekiwań na podstawie poprzednio opisanych badań, pochwały tłumaczy i ich pracy (70) przeważały zdecydowanie nad negatywnymi kategoriami zawierającymi dotyczące ich uwagi krytyczne (22) lub zgłaszane wątpliwości co do wierności/jakości tłumaczenia (45). Co ciekawe, wydaje się również, że wyrażanie wątpliwości ma często charakter czysto retoryczny, czyli jest podczas wielojęzycznej debaty odpowiednikiem fraz takich jak „o ile dobrze zrozumiałem”. Stosunkowo częste napomnienia (43) to skierowane do mówców (szczególnie przez przewodniczącego obrad) apele o dostosowanie wypowiedzi do potrzeb tłumaczenia symultanicznego, przede wszystkim przez ograniczenie tempa. Niepokoi fakt, że czasami napominani mówcy (szczególnie anglojęzyczni) otwarcie przeciwstawiają się takim apelom, stwierdzając, że nie widzą potrzeby tłumaczenia. Interesującą kategorią są wypowiedzi, w których mówcy sami sygnalizują pewne trudności tłumaczeniowe (np. żarty czy przysłowia), w pewien sposób usprawiedliwiając tłumaczy przed publicznością $\mathrm{w}$ przypadku niezbyt udanego tłumaczenia. Często towarzyszą temu przeprosiny skierowane bezpośrednio do tłumaczy. Co ciekawe, mówcy czasem przepraszają tłumaczy za coś, co powinno raczej stanowić dla tych drugich ułatwienie, np. za używanie języka ojczystego lub za mówienie „z głowy” zamiast czytania z kartki. Świadczy to co prawda o dobrych intencjach mówców, ale również o ich ignorancji w sferze prawdziwych oczekiwań co do tekstów źródłowych przeznaczonych do tłumaczenia symultanicznego. 


\section{Uwagi końcowe}

Mimo że instytucje unijne są największym na świecie pracodawcą tłumaczy ustnych, jeszcze do niedawna badacze tłumaczenia ustnego nie poświęcali im uwagi. Dziś mamy jednak do czynienia $\mathrm{z}$ bogactwem analiz empirycznych na temat tego specyficznego środowiska pracy. W dużej mierze przyczynia się do tego łatwa dostępność nagrań oraz stenogramów z sesji plenarnych PE, która zaowocowała licznymi badaniami korpusowymi. Badania antropocentryczne, skupiające się na samej osobie tłumacza, są rzadsze, ale nie mniej interesujące. Malowany przez nie obraz pracy tłumacza ustnego w PE jest bardzo niejednoznaczny. $Z$ jednej strony jest to praca prestiżowa i zapewniająca wysokie dochody, $\mathrm{z}$ drugiej - stresująca i powodująca wiele frustracji.

Komfort pracy tłumacza w dużym stopniu zależy od chęci współpracy ze strony mówców oraz zainteresowania słuchaczy. Tłumacze pracujący na potrzeby europosłów narodowości, wśród których znajomość języków obcych jest mniej rozpowszechniona, mogą mieć większe poczucie przydatności. Co do postaw mówców Sue Wright (2007) na podstawie wywiadów z europosłami oraz obserwacji ich wystąpień plenarnych zauważa istnienie dwóch radykalnie odmiennych grup. Pierwsza $\mathrm{z}$ nich świadomie redaguje swoje wypowiedzi i stara się używać jasnego i nieskomplikowanego języka na potrzeby odbiorców słuchających tekstu w języku obcym (na czym korzystają również tłumacze). Co ciekawe, deklaracje respondentów pokrywają się z ich zaobserwowanym zachowaniem językowym. Druga grupa natomiast w ogóle nie przykłada wagi do bycia rozumianym przez kogokolwiek poza swoimi rodakami. Należą do niej przede wszystkim rodzimi użytkownicy języków angielskiego i francuskiego. Wright nie wypowiada się na temat relatywnej wielkości tych dwóch grup. Niewątpliwie wskazane są dalsze badania nad wielojęzyczną komunikacją w PE i rolą, jaką odgrywają w niej tłumacze.

\section{Literatura}

Bartłomiejczyk M., 2016, Face threats in interpreting. A pragmatic study of plenary debates in the European Parliament, Katowice.

Bartłomiejczyk M., 2017, The interpreter's visibility in the European Parliament, „Interpreting”, 19(2), s. 159-185.

Beaton M., 2007, Intertextuality and ideology in interpreter-mediated communication. The case of the European Parliament, niepubl. praca doktorska, Heriot-Watt University. 
Beaton-Thome M., 2013, What's in a word? Your 'enemy combatant' is my 'refugee'. The role of simultaneous interpreters in negotiating the lexis of Guantánamo in the European Parliament, „Journal of Language and Politics", 12(3), s. 378-399.

Buchowska M., 2017, Tłumacz w instytucjach Unii Europejskiej. Wyzwania współczesnej wieży Babel, „Rocznik Przekładoznawczy. Studia nad teorią, praktyką i dydaktyką przekładu”, 12, s. 67-82.

Calzada Pérez M., 2001, A three-level methodology for descriptive-explanatory translation studies, „Target”, 13(2), s. 203-239.

Čeňková I., 2015, Relay interpreting, [w:] Routledge encyclopedia of interpreting studies, F. Pöchhacker (red.), London-New York, s. 339-341.

Cosmidou O., 2013, The European Parliament. A temple of multilingualism, a pioneer in interpreting 'exploits', „Gramma”, 19, s. 129-132.

Defrancq B., Plevoets K., 2018, The cognitive load of interpreters in the European Parliament. A corpus-based study of predictors for the disfluency $u h(m)$, „Interpreting”, 20(1), s. 1-32.

de Vicente F., 2011, European Union and translation, http://ec.europa.eu/ dgs/translation/workwithus/candidatecountries/documents/european_union_translation_en.pdf (dostęp: 28.12.2013).

Duflou V., 2016, Be(com)ing a conference interpreter. An ethnography of EU interpreters as a professional community, Amsterdam-Philadelphia.

Henriksen L., 2007, The song in the booth. Formulaic interpreting and oral textualisation, „Interpreting”, 9(1), s. 1-20.

Kajzer-Wietrzny M., 2013, Idiosyncratic features of interpreting style, „New Voices in Translation Studies", 9, s. 38-52.

Kent S. J., 2009, A discourse of danger and loss. Interpreters on interpreting for the European Parliament, [w:] The Critical Link 5. Quality in interpreting. A shared responsibility, L. Stern, U. Ozolins, S. B. Hale (red.), Amsterdam-Philadelphia, s. 55-70.

Kent S. J., 2014, Interpreting, niepubl. praca doktorska, University of Massachusetts Amherst.

Komisja Europejska, b.d., Interpretation in figures - 2015, http://ec.europa.eu/ dgs/scic/docs/about_dg_int/statistics-brochure.pdf (dostęp: 1.07.2016).

Koturbasz B., 2012, Ideology in the European Parliament. 'We' markers in one-minute speeches and their modifications in translated and interpreted discourse, niepubl. praca magisterska, Uniwersytet Gdański.

Kučiš V., Majhenič S., 2018, Cultural and stress-related manifestations of political controversial language in the European Parliament from the view of interpreters, „Babel”, 64(1), s. 33-62. 
Lejkowska-Abdelhazer K., 2018, Interpreting impoliteness. A case study on the basis of Nigel Farage's speech at the European Parliament in Strasbourg on $25^{\text {th }}$ November 2009, niepubl. praca magisterska, Uniwersytet Śląski.

Loupaki E., 2008, Shifts of involvement in translation. The case of European Parliament proceedings, [w:] New trends in translation and cultural identity, M. Muñoz-Calvo, C. Buesa-Gómez, M. Ángeles Ruiz-Moneva (red.), Newcastle upon Tyne, s. 105-116.

Magnifico C., Defrancq B., 2017, Hedges in conference interpreting. The role of gender, „Interpreting”, 19(1), s. 21-46.

Marzocchi C., 1998, The case for an institution-specific component in interpreting research, „The Interpreters' Newsletter”, 8, s. 51-74.

Monti C., Bendazzoli C., Sandrelli A., Russo M., 2005, Studying directionality in simultaneous interpreting through an electronic corpus: EPIC (European Parliament Interpreting Corpus), „Meta”, 50(4), s. 1079-1147.

Parlament Europejski, 2013, Towards more efficient and cost effective interpretation in the European Parliament, http://www.europarl. europa.eu/sides/getDoc.do?pubRef=-//EP//TEXT+REPORT+A7-2013-0233+0+DOC+XML+V0//EN (dostęp: 4.01.2015).

Phillipson R., 2003, English-only Europe? Challenging language policy, London-New York.

Pöchhacker F., 2004, Introducing interpreting studies, London-New York.

Pym A., 2008, Translation vs. language learning in international institutions. Explaining the diversity paradox, http://usuaris.tinet.cat/apym/on-line/ translation/2008_diversity_paradox.pdf (dostęp: 28.12.2013).

Russo M., 2010, Reflecting on interpreting practice. Graduation theses based on the EPIC, [w:] Translationswissenschaft - Stand und Perspektiven, L. Zybatow (red.), Frankfurt, s. 35-50.

Spinolo N., Garwood J., 2010, To kill or not to kill. Metaphors in simultaneous interpreting, „Forum”, 8(1), s. 181-211.

Van Dam H., Zethsen K. K., 2013, Conference interpreters - the stars of the translation profession? A study of the occupational status of Danish EU interpreters as compared to Danish EU translators, „Interpreting”, 15(2), s. $229-259$.

Vuorikoski A. R., 2004, A voice of its citizens or a modern tower of Babel? The quality of interpreting as a function of political rhetoric in the European Parliament, Tampere.

Wright S., 2007, English in the European Parliament. MEPs and their linguistic repertoires, „Sociolinguistica”, 27, s. 151-165. 


\section{Conference interpreters in the European Parliament}

\section{Summary}

The paper presents the working environment of EU interpreters in the European Parliament (EP), a setting with 24 working languages and 552 interpreting directions. It focuses on the specificity of plenary sessions and the challenges posed by the source texts (usually very short utterances, presented in a rapid succession and at a high speed, often in non-native English). Some attention is devoted to the multi-stage recruitment procedure, which should be of interest to potential candidates. Finally, the paper offers an outline of ethnographic research on EP interpreters that has been flourishing in recent years. The methods used by researchers include surveys, interviews, observation, participant observation, and content analysis of the material from plenary sessions. Some studies suggest that interpreters' satisfaction is lower than could be expected on the basis of the high prestige and income associated with the job. This is mostly attributable to uncooperative speakers and uninterested audiences. The author's own study (Bartłomiejczyk 2017) explores what participants of plenary sessions say about interpreters and interpreting. The results paint a more positive picture: appreciation is much more frequent than criticism and doubt. However, the frequency of reminders about the constraints of simultaneous interpreting addressed to speakers reinforces the observations of other authors that many speakers do not adjust their output to facilitate high-quality interpreting. Evidently, some of them are not ignorant of the requirements their speeches should meet, but they simply refuse to make any concessions.

Keywords: simultaneous interpreting, interpreter, European Parliament, ethnographic research

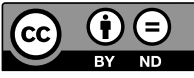

